\title{
MENGGALI KEARIFAN LOKAL MELALUI KAJIAN ETNOARKEOLOGI
}

\author{
H. Gunadi Kasnowihardjo \\ (Balai Arkeologi Yogyakarta)
}

\begin{abstract}
Local wisdom inherited by our ancestors has gradually been abandoned by present generation. Local wisdom actually taught us to live harmoniously with the surrounding environtment. As such, the environtment should be well - preserved for human own purposes. Ethno-archaeological studies could be used to unearth local wisdom of certain community or ethnic group. Eventually, this will provide added value to archaeological research.
\end{abstract}

Key words : Kearifan lokal, Warisan Nenek moyang, Etnoarkeologi, Manusia dan lingkungannya, Analogi etnografi.

\section{PENDAHULUAN}

Kearifan lokal dalam tulisan ini adalah nilai-nilai luhur yang dimiliki oleh masyarakat tradisional, terutama yang berkaitan antara kehidupan manusia dan alam lingkungannya. Hal ini berbeda dengan pengertian local genius yang sering diartikan dengan kepribadian budaya bangsa (Ayatrohaedi, 1986). Hal ini seperti pernah penulis ungkapkan pula dalam pengantar buku "Dinamika Kearifan Lokal Masyarakat Kalimantan" (2005) yang diterbitkan oleh Ikatan Ahli Arkeologi Indonesia, Komisariat Daerah Kalimantan. Istilah back to nature menurut hemat saya dapat diterapkan ke berbagai aspek kehidupan manusia. Karena dalam kehidupan sehari-hari manusia tidak dapat melepaskan diri dari pengaruh alam lingkungannya. Walaupun pada hakekatnya seluruh isi ala mini diperuntukkan kepada umat manusia, akan tetapi sumberdaya alam yang bersifat tidak terbarukan (unrenewable) jelas makin lama akan semakin habis. Selain itu, dalam pengelolaan sumberdaya alam yang tidak bertanggung jawab, seperti misalnya pada penebangan hutan dan penambangan perut bumi yang tidak terkendali dan tidak sesuai dengan tuntutan alam, akibatnya akan terjadi bencana yang dapat menghancurkan kehidupan manusia itu sendiri. Oleh karena itu sumberdaya alam yang bersifat tidak terbarukan tersebut sesegera mungkin dapat dicarikan penggantinya dengan sumberdaya yang dapat diperbarui (renewable).

Kajian etnoarkeologi yang merupakan salah satu pendekatan dalam penelitian arkeologi dengan fokus bahasan tentang analogi etnografi, adalah suatu kajian tentang perilaku masyarakat masa kini yang 
diperkirakan mempunyai kemiripan dengan perilaku masyarakat masa lampau berdasarkan artefak-artefak yang ditinggalkannya. Analogi etnografi atau dalam disiplin arkeologi sering disebut dengan behavioural archaeology, biasanya mengandung nilai-nilai kearifan dan nilai-nilai luhur yang saat kini sudah mulai ditinggalkan oleh masyarakat modern. Harus dipahami bahwa menggali hal-hal yang bersifat tradisional bukan berarti "ketinggalan jaman", begitu pula sebaliknya, tidak semua yang modern mesti baik dan cocok untuk diterapkan dalam kehidupan sekarang ini. Kajian etnoarkeologi juga dapat dikatakan sebagai upaya mencari pembenaran secara kognitif antara perilaku masyarakat masa kini dan dapat "dicocokkan" dengan perilaku masyarakat masa lampau. Selanjutnya nilai-nilai luhur tersebut dapat diterapkan kembali baik dalam konteks kehidupan masa sekarang maupun kehidupan dimasa yang akan datang.

\section{ETNOARKEOLOGI DAN ANALOGI ETNOGRAFI}

Pengertian etnoarkeologi menurut Paul Bahn dan Colin Renfrew (1991) adalah salah satu metode pendekatan dalam penelitian arkeologi, yaitu dengan melakukan kajian analogi etnografi pada masyarakat masa kini untuk tujuan merekonstruksi, menginterpretasikan, dan mengeksplanasikan tinggalan arkeologis (archaeological records). Dengan demikian dalam kajian etnoarkeologi tidak haya sekedar mendiskripsikan data etnografi, akan tetapi harus ditemukan data arkeologi yang akan ditelitinya. Beberapa contoh kajian etnoarkeologi antara lain seperti penelitian yang dilakukan oleh Richard Gould pada suku bangsa Aborigin di Australia, penelitian Richard Lee pada kelompok masyarakat Kung San di Afrika Selatan, dan penelitian Lewis R. Binford pada suku Nunamiut di Eskimo. Ketiga penelitian tersebut di atas berupaya menjelaskan tinggalan situs-situs arkeologi berdasarkan data etnografi yang ditemukan dari ketiga kelompok masyarakat yang sampai saat itu masih dapat ditelusuri dan dikaji perilaku mereka yang menunjukkan kemiripan dengan perilaku masyarakat masa lampau. Dalam buku "Archaeological Theory Today" yang dieditori oleh lan Hodder (2001) antara lain menjelaskan bahwa yang dimaksud dengan kajian etnoarkeologi adalah salah satu model pendekatan dalam unit analisis yang dikaitkan dengan behaviorial contexts, selanjutnya disebutkan bahwa dalam etnoarkeologi tersebut kata kuncinya adalah etnografi, sejarah, dan kasus arkeologi. Hal ini sama dengan yang dijelaskan oleh Gorecki (1988) yang menyatakan bahwa dalam penelitian situs-situs arkeologi saat ini sering digunakan data etnografi, arkeologi eksperimen, maupun taponomi.

Kesamaan dan kemiripan perilaku masyarakat masa kini dengan masyrakat masa lampau kemungkinan akan dapat dianalogikan apabila keduanya mempunyai hubungan persepsi, serta pemahaman kognitif yang baik. Harus disadari bahwa kajian analogi etnografi ini dalam menginterpretasikan data oleh Tim Murray (1988) dikatakan "terlalu berani", padahal data arkeologi tersebut tidak ontologism dengan data etnografi. 
Oleh karenanya ada tiga masalah yang harus diperhatikan dalam melakukan kajian analogi etnografi, yaitu:

1. Analogi etnografi akan dapat diterapkan apabila hipotesis tersebut digunakan untuk menganalisis hasil kebudayaan masa lampau yang berupa artefak arkeologis. Perlu dicatat pula bahwa tidak semua data etnografi dapat digunakan untuk interpretasi dan eksplanasi tinggalan arkeologi walaupun ditemukan di wilayah yang sama. Seperti kasus yang ditemukan pada petani di East Anglian, ternyata mereka bukan penghuni asli daerah tersebut, melainkan migran dari tempat lain yang tidak mempunyai hubungan dengan tinggalan arkeologis yang ditemukan.

2. Analogi etnografi merupakan muara dari perilaku arkeologis itu sendiri, tetapi perlu diperhatikan apabila hal tersebut didukung oleh adanya hubungan antara budaya masyarakat dan lingkungannya di satu pihak dan hubungan antara budaya materi dan perilaku manusia tersebut.

3. Etnoarkeologi adalah satu kajian yang dihasilkan dari analogi etnografi, akan tetapi tidak semua data etnografi dapat menghasilkan kajian etnoarkeologi (lain Davidson, 1988).

Adakah manfaat dari kajian etnoarkeologi? Seperti telah dibicarakan sebelumnya bahwa kajian etnoarkeologi akan dapat membantu menemu kenali bentuk-bentuk kearifan lokal dari suatu kelompok masyarakat yang sedang diteliti. Kebanyakan, bentuk-bentuk kearifan lokal tersebut pada saat ini sudah mulai ditinggalkan karena dianggap sudah tidak relevan dengan perkembangan jaman, bersifat tradisional, dan statis. Padahal, pendapat tersebut tidaklah benar, bahkan cenderung berlawanan, karena kearifan yang merupakan salah satu karya dan tinggalan adiluhung nenek moyang kita justru akan membawa kesejahteraan dan kemaslahatan umat manusia. Sebaliknya, hal-hal yang dianggap modern justru sering dapat berdampak menghancurkan dan menyengsarakan umat manusia. Berbagai pembangunan sarana dan prasarana yang secara fisik terlihat modern dan maju, akan tetapi dapat berdampak negative bagi kehidupan manusia (Kasnowihardjo, 2005a). Menengok kearifan lokal manusia masa lampau bukan berarti mundur kembali ke jaman purbakala. Cukup dengan mengambil nilai-nilai dan prinsip-prinsip yang terkandung di dalamnya, selanjutnya, dapat diterapkan dan disesuaikan dengan ilmu pengetahuan dan teknologi yang berkembang saat ini.

\section{KAJIAN ETNOARKEOLOGI DAN PERMASALAHAN MASA KINI}

Munculnya permasalahan yang akhir-akhir ini menjadi keprihatinan bangsa Indonesia salah satu di antaranya adalah merosotnya pemahaman budi pekerti bagi generasi muda penerus bangsa. Fenomena tersebut merupakan salah satu contoh akibat diabaikannya nilai-nilai kearifan lokal masyarakat masa lampau, yaitu tradisi lisan yang berupa dongeng-dongeng sebelum tidur yang selalu diajarkan kepada anak-anak usia TK - SD. Tradisi lisan seperti mendongeng yang dilakukan oleh orang tua kepada 
anak atau cucunya yang dilakukan setiap hari menjelang anak tidur malam, pada hakekatnya adalah proses memasukkan pemahaman nilai-nilai luhur kepada anak-anak mereka yang kelak setelah mereka dewasa, nilai-nilai luhur tersebut akan dapat dijadikan sebagai pegangan dalam kehidupannya. Sejak usia prasekolah mereka mulai "dicekoki" tentang contoh-contoh tentang nilai-nilai yang terpuji maupun yang tidak terpuji dengan akibat-akibatnya. Di sinilah hukum sebab-akibat telah ditanamkan, sehingga mereka akan dapat membedakan tentang kehidupan yang baik dan yang buruk.

Cerita dongeng yang hanya berkisar antara 4 - 5 judul, selalu diulang-ulang sepanjang tahun tidak menimbulkan kejenuhan dan kejemuan baik bagi yang mendongeng maupun bagi anak-anak yang mendengarkannya (sekalipun anak-anak bahkan telah hafal semua cerita atau dongeng tersebut), akan tetapi mereka tetap asyik mendengarkan hingga mereka tertidur. Demikian pula dengan pementasan wayang kulit, wayang orang, maupun ketoprak yang semuanya menceritakan tentang kehidupan dan perbuatan manusia beserta akibat-akibatnya. Sifat dan watak tokoh-tokoh sentral yang digambarkan dalam pertunjukan tersebut pada hakekatnya adalah gambaran bagi manusia tentang contoh-contoh perilaku yang bersifat hitam, putih, maupun abu-abu. Bagi kita yang menyimaknya tinggal menentukan pilihan mana yang akan kita jadikan panutan (Kasnowihardjo, 2005b). Memang, dalam perkembangan ilmu pengetahuan dan teknologi saat ini baik cerita dongeng, pentas wayang maupun pentas-pentas lain dapat diakses dari siaran radio, televisi, kaset, VCD, dan DVD. Akan tetapi efektifitasnya masih jauh dari yang diharapkan.

Keterpurukan ekonomi akhir-akhir ini apabila dikaitkan dengan kajian analogi etnografi, antara lain dapat ditarik dari berbagai kasus terutama yang berhubungan dengan pengelolaan sumberdaya alam, baik yang bersifat tidak terbarukan (unrenewable) maupun sumberdaya alam yang terbarukan (renewable). Salah satu contoh penelitian adalah tentang kawasan pertambangan tua di Sanga-Sanga, Kabupaten Kutai Kartanegara, Propinsi Kalimantan Timur. Dari hasil penelitian arkeologi ini diketahui bahwa pada saat itu di kalangan Bataviasch Petroleum Maatscappij (BPM) telah mampu memproduksi bahan bakar minyak (BBM) untuk kepentingan sendiri, seperti untuk kendaraan bermotor ataupun untuk keperluan seharihari lainnya (informasi dari para narasumber warga Sanga-Sanga mantan pekerja BPM). Teknologi pengolahan BBM yang sudah dikuasai pada awal abad XIX mestinya dapat dikembangkan saat perusahaan tersebut dikelola langsung oleh bangsa Indonesia setelah kemerdekaan. Rupa-rupanya teknologi tersebut tidak dikembangkan bahkan terkesan diabaikan, sehingga pemerintah kita hingga sekarang hanya dapat menjual minyak mentah ke Negara lain yang mampu memproduksinya dan membeli kembali minyak jadi dari luar negeri. Akibatnya, walaupun negeri ini memiliki cukup banyak tambang-tambang minyak bumi, akan tetapi tetap saja akan tergantung kepada Negara lain yang mampu memproduksi minyak mentah menjadi BBM. 
Untuk kasus dalam pengelolaan sumberdaya alam yang bersifat terbarukan, salah satu contoh kasus adalah Penelitian Permukiman Lingkungan Danau di Jawa Timur (Kasnowihardjo, 2007 dan Kasnowihardjo, 2008). Dari hasil penelitian tersebut selain ditemukan substansi akademis data arkeologi yang kontekstual dengan permukiman masa lampau, dapat dijelaskan pula bahwa kondisi danau-danau di Kabupaten Lumajang dan Probolinggo sangat tergantung dari kondisi hutan yang tumbuh di sekitar danau tersebut dan ini akan dipengaruhi oleh perilaku masyarakat setempat terhadap hutan mereka. Dengan kata lain, dapat disimpulkan bahwa kearifan masyarakat setempat dalam mengelola hutan tersebut akan berdampak kepada kondisi danau yang tergantung dari hutan yang akan mensuplai sumber air. Oleh karena itu untuk menjaga agar danau-danau di Jawa Timur tetap dapat menampung air guna kehidupan masyarakat yang bermukim di sekelilingnya, masyarakat harus tetap arif dalam menjaga lingkungan hutan yang ada disekitar danau tersebut (Kasnowihardjo, 2008).

Bencana alam yang selama ini menimpa bangsa Indonesia, beberapa di antaranya akibat dari ulah manusia yang dengan sengaja meninggalkan prinsip-prinsip kearifan masyarakat tradisional, salah satu contoh adalah penebangan dan penggundulan hutan yang "tanpa perhitungan". Padahal pengelolaan hutan yang baik sudah banyak dicontohkan oleh nenek moyang kita seperti model-model kearifan lokal yang ditemukan pada masyarakat di Kalimantan ataupun Sulawesi yang hingga kini masih ditemukan hutan-hutan lebat. Salah satu contoh ditemukan di kawasan Sungai Cerekang, Kabupaten Luwu Utara, Sulawesi Selatan, masyarakat yang tinggal di kawasan ini sampai sekarang masih mengkeramatkan satu areal hutan yang mereka namakan Hutan Ponsiwoni, sehingga tidak seorangpun berani mengganggu segala jenis tanaman yang tumbuh di areal hutan tersebut (Caldwell dan Bulbeck, 2000). Apabila diperhatikan dan dikaji secara materialisme, pemahaman yang bersifat idealistis di atas ternyata mengandung makna yang sangat dalam, yaitu model pelestarian lingkungan dalam rangka menjaga sumber air yang berasal dari kawasan hutan tersebut.

Demikian pula dengan model kearifan lokal yang ditemukan pada masyarakat Kajang di Kabupaten Bulukumba, Sulawesi Selatan. Mereka percaya bahwa semua jenis tanaman keras tidak boleh ditebang semaunya, apabila mereka memerlukan kayu, penebangan dapat dilakukan dengan mengikuti aturan dari pimpinan adat. Apabila ada warga yang melanggar aturan adat akan mendapatkan sangsi yang sangat berat. Kearifan lokal seperti contoh di atas banyak pula ditemukan di beberapa kawasan di Kalimantan, akan tetapi sangatlah disayangkan justru masyarakat asli yang sering dijadikan kambing hitam apabila terjadi kebakaran hutan (Lahajir, 2001). Padahal kebakaran hutan adalah salah satu akibat dari ulah manusia sekarang yang telah meninggalkan nilai-nilai luhur kearifan masyarakat tradisional. 


\section{PENUTUP DAN KESIMPULAN}

Mempelajari ilmu pengetahuan seperti ilmu antropologi dan arkeologi, maupun ilmu-ilmu humaniora lainnya, setidak-tidaknya ada dua sasaran. Pertama bersifat akademis, kajian ini bertujuan untuk mengetahui dan merekam pola-pola kehidupan masyarakat dalam segala aspek kehidupan, baik untuk masa sekarang maupun kehidupan dimasa lampau. Dalam kaitannya dengan kajian etnoarkeologi, hasil kajian etnografis dapat dimplementasikan dalam penelitian arkeologi yang nantinya akan dapat digunakan dalam merekonstruksi rangkaian sejarah kehidupan manusia di masa lampau. Kedua, bersifat praktis yaitu hasil dari kajian etnoarkeologi atau analogi etnografi ini diharapkan dapat memberikan manfaat yang riil bagi pengembangan dan perencanaan pembangunan pada suatu kawasan atau daerah demi kemaslahatan dan kesejahteraan masyarakat disekitar kawasan tersebut.

Sebagai penutup akan disimpulkan beberapa hal sebagai berikut :

1. Munculnya permasalahan bangsa yang berupa bencana alam yang terjadi di mana-mana beberapa tahun terakhir ini salah satu penyebabnya adalah karena ulah manusia yang telah meninggalkan kearifan lokal dan nilai-nilai luhur tinggalan nenek moyang.

2. Kajian-kajian analogi etnografi perlu diintensifkan dalam penelitian baik di bidang antropologi maupun arkeologi. Hasil kajian yang dapat menemu-kenali kembali tentang kearifan nilai-nilai luhur bangsa yang merupakan tinggalan nenek moyang tersebut dapat dijadikan acuan dalam perencanaan pembangunan bangsa diwaktu kini maupun yang akan datang.

3. Menengok, mengkaji dan mengimplementasikan nilai-nilai luhur dan cara hidup tinggalan nenek moyang bukanlah berarti mundur kembali ke jaman purbakala. Salah satu contoh tradisi lisan seperti yang disampaikan dengan cara mendongeng secara rutin setiap malam kepada anak-anak menjelang tidur, ternyata sangat efektif dalam membangun budi pekerti generasi muda sebagai calon penerus bangsa kita (nation character building). Demikian pula dalam pengelolaan hutan yang sangat terkait dengan sumber air yang merupakan sumber kehidupan manusia, kita perlu mengacu kepada nilai-nilai luhur yang pernah diajarkan oleh nenek moyang, apabila kita akan selamat dan ingin mewariskannya kepada anak cucu kita sesuatu yang bermanfaat bagi kehidupan mereka kelak. 


\section{KEPUSTAKAAN}

Ayatrohaedi, (Penyunting) 1986. Kepribadian Budaya Bangsa (Local Genius), Jakarta: Dunia Pustaka Jaya dan Ikatan Ahli Arkeologi Indonesia.

Bahn, Paul and Colin Renfrew, 1991. Archaeology, Theories, Methods and Practice, Thames and Hudson, USA.

Caldwell, Ian and David Bulbeck, 2000. Land of Iron, The historical archaeology of Luwu and Cenrana valley, Centre for South-East Asian Studies, The University of Hull and School of Archaeology and Anthropology, Australian National University, Hull and Canberra.

Davidson, lain, 1988. "The naming of parts: ethnography and the interpretation of Australian prehistory", dalam: Betty Meehan and Rhys Jones: Archaeology With Ethnography an Australian Perspective, Department of Prehistory, Research School of Pacific Studies, Canberra : The Australian National University.

Kasnowihardjo, Gunadi, 2005a. "Lingkungan Aquatik dan Model Kearifan Lokal Masyarakat Banjar", dalam Dinamika Kearifan Lokal Masyarakat Kalimantan, Ikatan Ahli Arkeologi Indonesia, Komisariat Daerah Kalimantan.

2005b. "Wayang Banjar dan Upaya Pelestariannya: Satu Upaya Melestarikan Nilai Adiluhung Bangsa", Kongres Pewayangan 2005, Yogyakarta, 14 - 18 September 2005.

2007. "Penelitian dan Pengembangan Situs Permukiman Lingkungan Danau di Jawa Timur : Satu Upaya Menjalin Kemitraan dalam Pengelolaan Sumberdaya Arkeologi", Berkala Arkeologi, Tahun XXVII Edisi No. 2/ November 2007.

2008. "Permukiman Masa Lampau di Tepian Danau, Desa Ranugedang, Tiris, Probolinggo, Jawa Timur", Laporan Penelitian Arkeologi, Yogyakarta: Balai Arkeologi Yogyakarta, Belum terbit.

Lahajir, 2002. Etnologi Perladangan Orang Dayak Tunjung, Diterbitkan atas kerjasama antara Yayasan IKAPI dan The Ford Foundation.

MacDonald, Margaret Read, 2003. Cerita-Cerita Pelestarian Lingkungan, Cerita Rakyat dari Berbagai Penjuru Dunia, Edisi Bahasa Indonesia, Diterbitkan oleh Penerbit Kanisius Yogyakarta. 
Murray, Tim, 1988. "Ethnoarchaeology or Palaeoethnology?", dalam Betty Meehan and Rhys Jones: Archaeology With Ethnography, an Australian Perspective, Canberra: Department of Prehistory, Research School of Pacific Studies, The Australian University. 